\section{$\underset{\substack{\text { hommes } \\ \text { \& migrations }}}{ }$}

\section{Hommes \& migrations}

Revue française de référence sur les dynamiques

migratoires

$1309 \mid 2015$

Le 3e âge des migrants

\title{
Perdus entre deux rives, les chibanis oubliés
}

Documentaire français de Rachid Oujdi

\section{Anaïs Vincent}

\section{OpenEdition \\ 1 Journals}

\section{Édition électronique}

URL : http://journals.openedition.org/hommesmigrations/3124

DOI : 10.4000/hommesmigrations.3124

ISSN : 2262-3353

\section{Éditeur}

Musée national de l'histoire de l'immigration

\section{Édition imprimée}

Date de publication : 1 janvier 2015

Pagination : 200-201

ISBN : 978-2-919040-30-8

ISSN : 1142-852X

Référence électronique

Anaiis Vincent, «Perdus entre deux rives, les chibanis oubliés », Hommes \& migrations [En ligne], 1309 |

2015, mis en ligne le 31 août 2015, consulté le 24 septembre 2020. URL : http://

journals.openedition.org/hommesmigrations/3124; DOI : https://doi.org/10.4000/

hommesmigrations.3124

Ce document a été généré automatiquement le 24 septembre 2020.

Tous droits réservés 


\title{
Perdus entre deux rives, les chibanis oubliés
}

\author{
Documentaire français de Rachid Oujdi
}

\section{Anaïs Vincent}

1 Un homme de dos contemple la Méditerranée. En face, son pays d'origine l'Algérie lui est devenu étranger. Ainsi s'ouvre Perdus entre deux rives, les chibanis oubliés: sur un constat désenchanté.

2 La caméra arpente les ruelles, les cafés et les foyers de Marseille à la rencontre des chibanis, ces "vieillards" ou "cheveux blancs" en arabe. Ahmou, Mohammed, Abdallah, Sebtir nous racontent leur histoire. Venus du rivage opposé entre 1951 et 1971, ces Algériens ont immigré en France pour trouver du travail. Ils ne pensaient pas rester : un an, deux tout au plus, et ils rentreraient retrouver leur famille. Mais le destin en a voulu autrement. Ils sont maintenant retraités et vivent toujours dans la cité phocéenne, le cœur déchiré entre leur terre natale et leur pays d'adoption.

3 Rachid Oujdi collecte leurs témoignages avec bienveillance et essaie de comprendre comment ces hommes qui ont donné leur vie à la nation française peuvent aujourd'hui se terrer dans l'ombre de la pauvreté, loin de leurs proches.

4 Les extraits de magazines d'actualité de l'époque et la voix posée d'Ali Timizar, président du comité d'intérêt de quartier, contextualisent les récits de ces chibanis. Absence de voix off, Rachid Oujdi s'efface pour laisser la parole à ses témoins. Ils reviennent sur un passé tiraillé entre deux pays n'appartenant finalement à aucun d'entre eux. "Quand je suis en Algérie, je suis émigré, et quand je suis en France, je suis étranger", confie Tahar.

5 Lors d'une partie de dominos dans un café de Belzunce, ils se souviennent de l'insalubrité de leur logement. Ces bidonvilles qui furent longtemps "la mauvaise conscience" des villes.

6 Sidérurgistes, ouvriers du bâtiment, grutiers, brigadiers, ces travailleurs précaires ne gagnaient pas suffisamment pour pouvoir repartir, comme ils l'expliquent tour à tour au fil des interviews. Pris dans l'engrenage de la vie active et de la survie, ils n'ont eu 
d'autre choix que de rester à Marseille en se coupant un peu plus de leurs proches restés au pays, en s'enfonçant dans la solitude.

7 Prisonniers de leur situation, ils ont dû renoncer à leur vie de famille.

8 Ni militantisme exacerbé, ni misérabilisme dans ce documentaire télévisuel. Les protagonistes continuent leur combat sans jamais se plaindre, avec même une profonde reconnaissance pour leur terre d'accueil qui les a pourtant délaissés.

9 La sortie récente de Perdus entre deux rives, les chibanis oubliés est l'occasion de découvrir ou de redécouvrir ce documentaire déjà diffusé sur France 3 et sur LCP. 